\title{
Correction to: Vascular endothelial PDPK1 plays a pivotal role in the maintenance of pancreatic beta cell mass and function in adult male mice
}

\author{
Atsushi Obata ${ }^{1} \cdot$ Tomohiko Kimura $^{1} \cdot$ Yoshiyuki Obata $^{1} \cdot$ Masashi Shimoda ${ }^{1} \cdot$ Tomoe Kinoshita $^{1} \cdot$ Kenji Kohara $^{1}$. \\ Seizo Okauchi ${ }^{1} \cdot$ Hidenori Hirukawa $^{1}$. Shinji Kamei ${ }^{1}$. Shuhei Nakanishi ${ }^{1} \cdot$ Tomoatsu Mune $^{1} \cdot$ Kohei Kaku $^{1}$. \\ Hideaki Kaneto ${ }^{1}$
}

Published online: 11 October 2019

(C) Springer-Verlag GmbH Germany, part of Springer Nature 2019

\section{Correction to: Diabetologia}

https://doi.org/10.1007/s00125-019-4878-1

It has been brought to our attention that Fig. 5a showing the vasculature in islets of control flox mice is not in fact an endocrine cell but, rather, exocrine tissue. In the new Fig. 5a presented here we show the vasculature adjacent to pancreatic beta cells of control flox mice. In addition, the $\times 5000$ image in the left-hand panel of Fig. $5 \mathrm{~b}$ is replaced by a lower-resolution image $(\times 3000)$ to provide a broader cellular context.
The online version of the original article can be found at https:/doi.org/ $10.1007 / \mathrm{s} 00125-019-4878-1$

Atsushi Obata

obata-tky@med.kawasaki-m.ac.jp

1 Department of Diabetes, Endocrinology and Metabolism, Kawasaki Medical School, 577 Matsushima, Kurashiki 701-0192, Japan
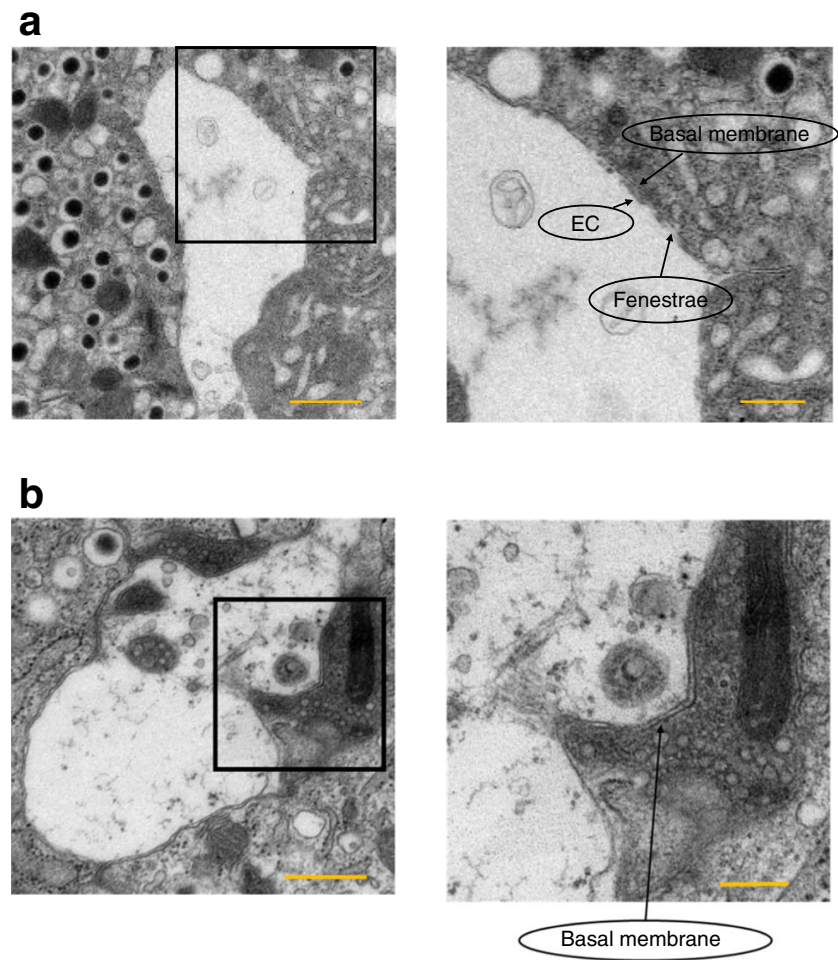

Fig. 5 Vascular structure of islets from VE-PDPK1-KO mice and control flox mice. Electron microscopic images showing capillaries surrounded by pancreatic beta cells in (a) control flox mice and (b) VE-PDPK1-KO mice. EC, endothelial cells. Images are representative of four mice. Magnification $\times 5000(\mathbf{a}$, left $)$ or $\times 3000(\mathbf{b}$, left) scale bars, $1 \mu \mathrm{m}$; or $\times 10,000$ (right), scale bars, $500 \mathrm{~nm}$ 